\title{
Biphasic modulation of insulin receptor substrate-1 during goitrogenesis
}

\section{R. Grozovsky, \\ M.M. Morales ${ }^{2}$ and D.P. Carvalho ${ }^{1}$}

\author{
${ }^{1}$ Laboratório de Fisiologia Endócrina, ${ }^{2}$ Laboratório de Fisiologia Celular e Molecular, \\ Instituto de Biofísica Carlos Chagas Filho, Universidade Federal do Rio de Janeiro, \\ Rio de Janeiro, RJ, Brasil
}

\author{
Correspondence \\ D.P. Carvalho \\ Laboratório de Fisiologia Endócrina \\ Instituto de Biofísica \\ Carlos Chagas Filho, UFRJ \\ CCS, Bloco G, Ilha do Fundão \\ 21949-900 Rio de Janeiro, RJ \\ Brasil \\ Fax: +55-21-2280-8193 \\ E-mail: dencarv@biof.ufrj.br \\ Research supported by FAPERJ, \\ $\mathrm{CNPq}$ and Howard Hughes Medical \\ Institute (No. 55003669). \\ R. Grozovsky was the recipient \\ of a fellowship from CAPES.
}

Received March 21, 2006 Accepted January 19, 2007

\begin{abstract}
Insulin receptor substrate-1 (IRS-1) is the main intracellular substrate for both insulin and insulin-like growth factor I (IGF-I) receptors and is critical for cell mitogenesis. Thyrotropin is able to induce thyroid cell proliferation through the cyclic AMP intracellular cascade; however, the presence of either insulin or IGF-I is required for the mitogenic effect of thyroid-stimulating hormone (TSH) to occur. The aim of the present study was to determine whether thyroid IRS-1 content is modulated by TSH in vivo. Strikingly, hypothyroid goitrous rats, which have chronically high serum TSH levels (control, $\mathrm{C}=2.31$ \pm 0.28 ; methimazole $(\mathrm{MMI}) 21 \mathrm{~d}=51.02 \pm 6.02 \mathrm{ng} / \mathrm{mL}, \mathrm{N}=12$ rats), when treated with $0.03 \% \mathrm{MMI}$ in drinking water for 21 days, showed significantly reduced thyroid IRS-1 mRNA content. Since goiter was already established in these animals by MMI for 21 days, we also evaluated IRS-1 expression during goitrogenesis. Animals treated with MMI for different periods of time showed a progressive increase in thyroid weight $(\mathrm{C}=22.18 \pm 1.21$; MMI $5 \mathrm{~d}=32.83 \pm 1.48$; MMI 7d $=31.1 \pm 3.25$; MMI $10 \mathrm{~d}=33.8 \pm 1.25 ;$ MMI $14 \mathrm{~d}=45.5 \pm 2.56$; MMI $18 \mathrm{~d}=53.0 \pm 3.01 ;$ MMI $21 \mathrm{~d}=61.9 \pm 3.92 \mathrm{mg}, \mathrm{N}=9-15$ animals per group $)$ and serum TSH levels $(\mathrm{C}=1.57 \pm 0.2$; MMI $5 \mathrm{~d}=9.95 \pm 0.74$; MMI 7d = 10.38 \pm 0.84; MMI 10d $=17.72 \pm 1.47$; MMI 14d $=25.65$ \pm 1.23 ; MMI 18d = 35.38 \pm 3.69 ; MMI $21 \mathrm{~d}=31.3 \pm 2.7 \mathrm{ng} / \mathrm{mL}, \mathrm{N}=$ 9-15 animals per group). Thyroid IRS-1 mRNA expression increased progressively during goitrogenesis, being significantly higher by the 14th day of MMI treatment, and then started to decline, reaching the lowest values by the 21 st day, when a significant reduction was detected. In the liver of these animals, however, a significant decrease of IRS-1 mRNA was detected after 14 days of MMI treatment, a mechanism probably involved in the insulin resistance that occurs in hypothyroidism. The increase in IRS-1 expression during goitrogenesis may represent an important event associated with the increased rate of cell mitosis promoted by TSH and indicates that insulin and IGF-I are important co-mitogenic factors in vivo, possibly acting through the activation of IRS-1.
\end{abstract}

Key words

- Thyroid

- Goiter

- Insulin receptor substrate

- Insulin

- Thyrotropin

$\ldots \ldots \ldots \ldots \ldots \ldots \ldots$

\section{Introduction}

Thyroid gland proliferation is under the control of several hormones and growth fac- tors (1-3). Thyroid-stimulating hormone (TSH) is the main regulator of thyroid cell function and proliferation, although several studies using cell culture systems have es- 
tablished that TSH alone is not a mitogenic factor. In fact, progression of the thyroid cell cycle depends on the concerted action of TSH and insulin and/or insulin-like growth factor I (IGF-I), which function as co-mitogenic factors (1-6). Previous studies have demonstrated the presence of IGF-I (IGFIR) and insulin (IR) receptors in thyrocytes in culture and in human thyroid tissues $(4,7)$. IGF-I can also act as a co-mitogenic factor in vivo, since high goiter prevalence is found in acromegaly, a disease characterized by elevated serum IGF-I levels (8). Furthermore, transgenic mice overexpressing IGF-I and IGF-IR in the thyroid have lower TSH requirements and goiter (9).

The main physiological action of insulin involves glucose, protein and lipid metabolism, whereas IGF-I acts mainly as a mitogenic hormone (10). Insulin and IGF-I bind to different receptors that have a high degree of homology and share a common intracellular pathway. Activation of either IGF-IR or IR triggers a tyrosine kinase intracellular pathway leading to the phosphorylation of insulin receptor substrate-1 (IRS-1), the main IR and IGF-IR substrate $(11,12)$. The phosphorylated tyrosine residues of IRS-1 are recognized by molecules containing an Src homology 2 domain, which include the growth factor receptor-bound protein and the $85-\mathrm{kDa}$ regulatory subunit of phosphatidyl-inositol 3 kinase. The phosphatidyl-inositol 3 kinase signaling pathway mediates many cellular events, including increased cellular proliferation (13).

IRS-1 activation is critical for cell mitogenesis and its overexpression is associated with neoplastic transformation (14). Thus, IRS-1 plays an important role in both cell proliferation and differentiation. In cell cultures, TSH positively modulates IR expression through cAMP, in addition to increasing IR and IGF-IR autophosphorylation $(4,15)$. Taken together, these findings seem to be important for cell cycle progression and mitosis, although under certain experi- mental conditions IGF-IR number and kinase activity were not increased by cAMP (16).

In FRTL-5 cells, TSH modulates IR substrates via the cAMP cascade (17). Thus, the aim of the present study was to evaluate the regulation of thyroid IRS-1 expression during a mitogenic stimulus in vivo. We show that in hypothyroid goitrous animals, with chronically increased serum TSH levels, thyroid IRS-1 mRNA and protein expression are down-regulated, while during goitrogenesis a biphasic modulation is observed, with an increased IRS- 1 content coinciding with the time of greater thyroid weight increase. Thus, depending on the rate of thyroid cell proliferation, the intracellular pathways may be differently regulated. The present data can probably explain, at least in part, the controversial findings regarding thyroid cell proliferation in cell culture models.

\section{Material and Methods}

\section{Material}

L-thyroxine, methimazole (MMI), bovine serum albumin, and chemicals for protein extraction were from Sigma (St. Louis, MO, USA); anti-IRS-1 primary antibody (goat $\operatorname{IgG}$ ) and secondary anti-goat IgG antibody were purchased from Santa Cruz (Santa Cruz, CA, USA). Chemicals for RNA extraction and RT-PCR were purchased from Invitrogen Corporation (Carlsbad, CA, USA), 4',6'-diamidino-2-phenylindole (DAPI) was purchased from Calbiochem (San Diego, CA, USA) and ECL reagent for chemiluminescence was from Amersham (Buckinghamshire, England).

\section{Animals}

Adult male Wistar rats weighing 200 to $250 \mathrm{~g}$ were housed under controlled conditions of temperature $\left(24 \pm 1^{\circ} \mathrm{C}\right)$ and light (12-h light starting at 7:00 am). All experi- 
ments were conducted in accordance with standards of animal care and were approved by the Institutional Committee for Evaluation of Animal Use in Research (CAUAP/ IBCCF). Rats were divided into two experimental groups: hypothyroidism was induced by the addition of $0.03 \%$ MMI to the drinking water for 21 days and control rats received water ad libitum.

In order to evaluate IRS-1 modulation during goitrogenesis, rats were divided into seven experimental groups. A control group received water ad libitum, and goiter was induced in the seven experimental groups by $0.03 \%$ MMI treatment in drinking water for different periods of time $(5,7,10,14,18,21$, and 26 days). Experiments were designed in such a way that all animals were sacrificed on the same day. In each experimental group, 9-15 animals were used.

\section{RNA extraction and RT-PCR}

Total RNA was extracted from a pool of two rat thyroid glands or $50 \mathrm{mg}$ of liver using Trizol $^{\circledR}$ reagent according to the manufacturer's protocol. RNA samples were treated with deoxyribonuclease I (Boehringer, Mannheim, Germany) in order to destroy possible DNA contamination. RNA was quantitated by absorbance at $260 \mathrm{~nm}$ using a Hitachi spectrophotometer (U-3000, Tokyo, Japan), and RNA integrity was tested by separating the samples by $0.8 \%$ agarose gel electrophoresis.

First-strand complementary DNA (cDNA) was synthesized using different amounts of purified RNA, $50 \mu \mathrm{M}$ Oligo dT, $1 \mathrm{U}$ reverse transcriptase (Superscript RNase H-reverse transcriptase), $5 \mathrm{X}$ first strand buffer, $10 \mathrm{U}$ RNAsin, and $10 \mu \mathrm{M}$ dNTP. cDNA was submitted to the polymerase chain reaction (PCR) using specific primers for rat IRS-1 (50 pmol): forward: 5'-CACCCAGTTTTT CGACAC-3', and reverse: 5'-GAGTTGAGC TTCACAAAG-3'. The rat B-actin primers (20 pmol) predicted to amplify the 226-bp
PCR product (sense: 5'-TATGCCAACACA GTGCTGTCTGG-3'; antisense: 5'- AAGAA AGCAAGACAGTGATTGTG-3') were used as an internal control. Thirty-five cycles PCR were used in the following conditions: $94^{\circ} \mathrm{C}$ for $30 \mathrm{~s}, 50^{\circ} \mathrm{C}$ for $45 \mathrm{~s}, 72^{\circ} \mathrm{C}$ for $45 \mathrm{~s}$.

The semi-quantitative RT-PCR methods used were validated in preliminary experiments. First, the optimal PCR conditions that yielded a single band by agarose gel electrophoresis were determined for each gene in the same reaction tube. Second, to determine whether the method was semiquantitative, serial quantities of total RNA from thyroids $(62.5,125,250,500,1000$, $2000 \mathrm{ng}$ ) were used for semi-quantitative RT-PCR amplification of both IRS-1 and Bactin, as described before (18). Then, $250 \mathrm{ng}$ RNA was used for the synthesis of cDNA for semi-quantitative RT-PCR. All reactions included a negative control (cDNA made from $250 \mathrm{ng}$ of total RNA isolated from thyroid glands in the absence of reverse transcriptase) (data not shown).

\section{Immunoprecipitation and Western blot analysis}

Pools of three rat thyroid glands from each group were homogenized with an ultraturrax blender (IKA Werke, Staufen, Germany) in $0.5 \mathrm{~mL} 50 \mathrm{mM}$ HEPES, pH 7.4, and $10 \mathrm{mM}$ EDTA buffer containing $1 \%$ Triton X-100, $10 \%$ glycerol, $100 \mathrm{mM}$ sodium fluoride, $100 \mathrm{mM}$ sodium pyrophosphate, $2 \mathrm{mM}$ PMSF, and $0.1 \mathrm{mg} / \mathrm{mL}$ aprotinin.

The homogenates were centrifuged at $200,000 \mathrm{~g}$ at $4^{\circ} \mathrm{C}$ in a Beckman 70.1 Ti rotor (Fullerton, CA, USA) for $1 \mathrm{~h}$. Protein concentration in the supernatant was measured by the method of Bradford (19) and $1 \mathrm{mg} /$ $\mathrm{mL}$ protein was incubated with $0.8 \mu \mathrm{g}$ antiIRS-1 antibody (goat $\mathrm{IgG}$ ) for $18 \mathrm{~h}$ at $4^{\circ} \mathrm{C}$. Immunocomplexes were collected on protein A - Sepharose beads (Pharmacia Biotech, Piscataway, NJ, USA) and washed three 
times. The pellets containing immunoprecipitated IRS- 1 were resuspended in Laemmli sample buffer (20) and resolved by polyacrylamide gel electrophoresis (6.5\% SDSPAGE). Proteins were transferred to a PVDF membrane (Millipore, Billerica, MA, USA), which was then blocked with $0.5 \%$ BSA and $2 \%$ low-fat dry milk in phosphate buffer containing $0.1 \%$ Tween (PBS-Tween). The membrane was washed three times with PBSTween and incubated with an anti-IRS-1 antibody (1:500 dilution) for $2 \mathrm{~h}$. Immunoblotting was performed using horseradish peroxidase-conjugated anti-goat $\operatorname{IgG}(1: 2000$ dilution). The bands corresponding to IRS-1 were visualized by ECL and quantified by densitometry using the ScionImage software (NIH image).

\section{Serum $\mathrm{T}_{4}$ and $\mathrm{TSH}$ determinations}

Serum total $\mathrm{T}_{4}$ was assayed using commercial kits (DPC - Diagnostic Products Corporation, Los Angeles, CA, USA), and $\mathrm{T}_{4}$ standard curves were constructed with hormone-free rat serum. Serum TSH was determined by a specific radioimmunoassay using primary antibodies for rat TSH and the standard curve provided by the National Hormone and Peptide Program/NIDDK (Bethesda, MD, USA).

Table 1. Serum thyroxine and thyroid-stimulating hormone (TSH) levels of hypothyroid rats.

\begin{tabular}{lcrc}
\hline Groups & $\mathrm{T}_{4}(\mu \mathrm{g} / \mathrm{dL})$ & $\mathrm{TSH}(\mathrm{ng} / \mathrm{mL})$ & Thyroid weight $(\mathrm{mg})$ \\
\hline Control & $2.25 \pm 0.27^{\mathrm{a}}$ & $1.57 \pm 0.20^{\mathrm{a}}$ & $22.2 \pm 1.21^{\mathrm{a}}$ \\
MMI for 5 days & $1.16 \pm 0.11^{\mathrm{b}}$ & $9.95 \pm 0.74^{\mathrm{b}}$ & $32.8 \pm 1.48^{\mathrm{b}}$ \\
MMI for 7 days & $0.99 \pm 0.16^{\mathrm{b}}$ & $10.38 \pm 0.84^{\mathrm{b}}$ & $31.1 \pm 3.25^{\mathrm{b}}$ \\
MMI for 10 days & ND & $17.72 \pm 1.47^{\mathrm{C}}$ & $33.8 \pm 1.25^{\mathrm{b}}$ \\
MMI for 14 days & ND & $25.65 \pm 1.23^{\mathrm{d}}$ & $45.5 \pm 2.56^{\mathrm{c}}$ \\
MMI for 18 days & ND & $35.38 \pm 3.69^{\mathrm{e}}$ & $53.02 \pm 3.01^{\mathrm{c}}$ \\
MMI for 21 days & ND & $31.30 \pm 2.70^{\mathrm{e}}$ & $61.9 \pm 3.92^{\mathrm{C}}$ \\
\hline
\end{tabular}

Control male Wistar rats (200 to $250 \mathrm{~g}$ ) received water ad libitum. Hypothyroid rats were treated with $0.03 \%$ methimazole (MMI) in drinking water for different periods of time. Data are reported as means \pm SEM for 9-15 animals in each group. Different letters indicate statistically significant differences at $\mathrm{P}<0.01$ (ANOVA followed by the Newman-Keuls multiple comparison test). Serum TSH values were logarithmic transformed before statistical analysis. ND $=$ non-detectable.

\section{DAPI-staining}

Paraffin-embedded thyroid tissue samples were fixed with 70,75 , and $90 \%$ ethanol for 10 min. After washing in PBS, thyroid tissue slices were stained by applying a 1:500 diluted DAPI solution for $5 \mathrm{~min}$, rinsed with PBS, mounted with glycerol, and evaluated by fluorescent microscopy for nucleus counting.

\section{Statistical analysis}

Data were analyzed statistically by oneway analysis of variance (ANOVA) followed by the Newman-Keuls multiple comparison test. Serum TSH levels were analyzed after logarithmic transformation.

\section{Results}

Hypothyroid animals had significantly lower serum $\mathrm{T}_{4}$ levels (control $=3.47 \pm 0.29$ $\mu \mathrm{g} / \mathrm{dL} ;$ hypothyroid $=$ non-detectable) and increased TSH levels (control $=2.31 \pm 0.28$; hypothyroid $=51.02 \pm 6.02 \mathrm{ng} / \mathrm{mL}, \mathrm{P}<$ 0.001 ).

In long-term hypothyroid animals, thyroid IRS-1 mRNA was significantly downregulated when compared to control animals (data not shown). However, thyroid IRS-1 protein content did not decrease significantly in hypothyroid animals (data not shown). Interestingly, decreased mRNA expression was not accompanied by decreased protein content, as determined by immunoprecipitation analysis.

Since TSH induces goiter, and insulin and IGF-I are important co-mitogenic factors in vitro, the finding of down-regulated IRS-1 with increased serum TSH levels was unexpected since IRS-1 is the main IR and IGF-IR intracellular substrate. Either other IRSs are involved or the decrease in IRS-1 when goiter is already established may represent a physiological control of thyroid mitogenesis. Another possibility is that decreased thyroid IRS-1 might be secondary to 
the insulin resistance that is established during hypothyroidism. Thus, we tested IRS-1 expression during goitrogenesis in thyroid and liver. Animals treated with MMI for different periods of time showed a progressive decrease in serum $\mathrm{T}_{4}$ with a corresponding increase in serum TSH (Table 1) and in cell numbers (Figure 1) and the consequent development of goiter. Thyroid weight and serum TSH levels increased progressively until the 18th day of MMI treatment (Table 1). Thyroid IRS-1 mRNA (Figure 2A) and protein expressions (Figure 2B) increased progressively during goitrogenesis until the 14th day of MMI treatment and started to decline thereafter, reaching the lowest values by the 21 st day of treatment, when a significant reduction was detected compared to all other groups, including control animals. Protein expression analysis showed that the decreased IRS-1 protein expression seemed to be sustained until at least the 26th day of MMI treatment (Figure 2B), when no more increase in thyroid weight was detected, indicating that the down-regulation of IRS-1 might be important for the mainte-
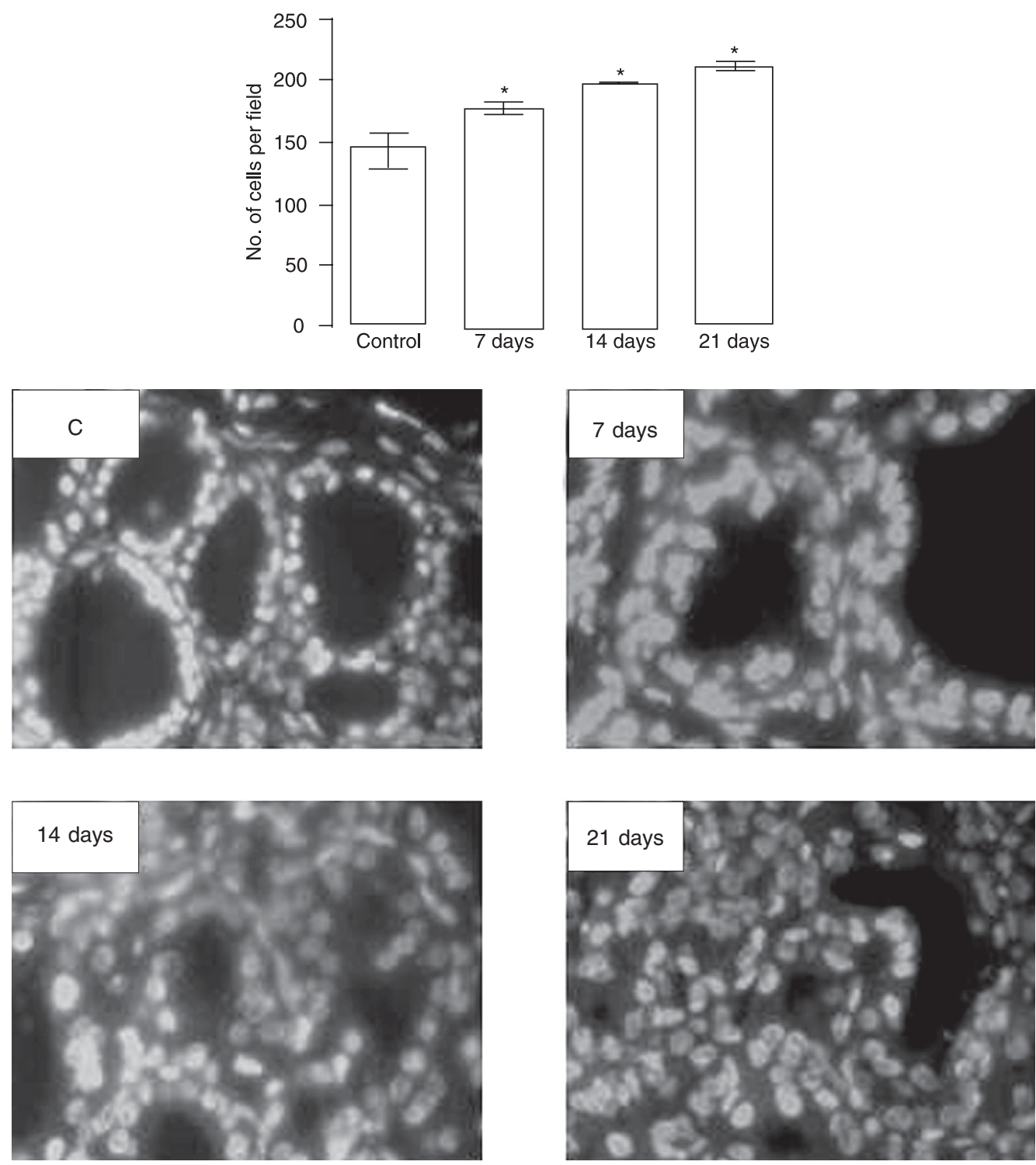

Figure 1. Increase in thyroid cell number during goitrogenesis. Thyroid tissue from rats treated with $0.03 \%$ methimazole in drinking water during different periods of time $(7,14$, and 21 days) and from control (C) rats was embedded in paraffin and tissue sections were stained with 4',6'-diamidino-2-phenylindole for nucleus count. Data are reported as the mean \pm SEM of three experiments with at least 3 rats in each group. ${ }^{*} P$ $<0.05$ compared to control (ANOVA followed by the Newman-Keuls multiple comparison test). $40 \mathrm{X}$ magnification. 


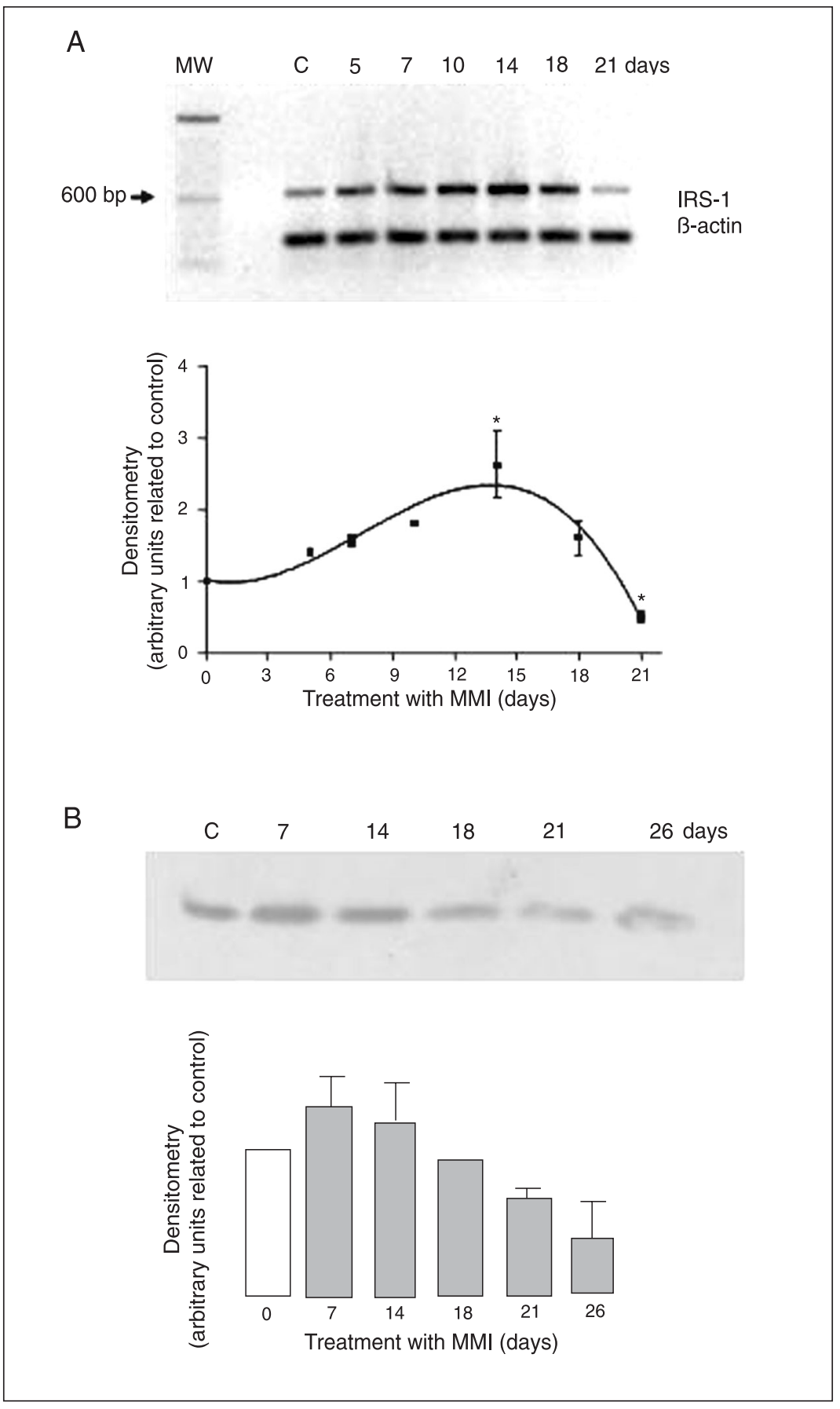

Figure 2. Thyroid insulin receptor substrate-1 (IRS-1) mRNA (A) and protein (B) expression during goitrogenesis in rats. Thyroid IRS-1 mRNA expression (A) was analyzed by semiquantitative RT-PCR and IRS-1 protein expression (B) was analyzed by immunoprecitation followed by immunoblotting with anti-IRS-1 antibody. Goiter was induced by treatment with $0.03 \%$ methimazole (MMI) in drinking water for different periods of time $(5,7,10,14,18,21$, and 26 days). Data are reported as the mean \pm SEM of $2-3$ rats per group in three experiments in $A$ and the mean and the maximal value of two different experiments in $B$. ${ }^{*} \mathrm{P}$ $<0.01$ compared to control (C, 14 days) and to the other periods of MMl treatment (21 days; ANOVA followed by the Newman-Keuls multiple comparison test). $\mathrm{MW}=$ molecular weight. nance of thyroid gland weight without a further increase between 21 and 26 days. On the other hand, liver IRS-1 mRNA (Figure 3) was significantly decreased on the 14th day of MMI treatment and continued to be low until the 21st day of treatment.

\section{Discussion}

The objective of the present study was to evaluate the modulation of the main insulin receptor substrate, IRS-1, by TSH in vivo. IRS-1 is the immediate substrate of IR, IGFIR, RET, and other tyrosine kinase intracellular pathways, being phosphorylated in multiple tyrosine residues that serve as docking sites for a variety of signaling molecules, the activation of which is critical for cell mitogenesis (21). Since insulin and IGF-I are fundamental for TSH-induced thyroid mitogenesis, TSH might regulate their common intracellular substrates.

In FRTL-5 cell cultures, TSH treatment did not induce any changes in either IRS-1 phosphorylation or IRS-1 amount (17). In the present study, IRS-1 expression was significantly decreased in hypothyroid animals with chronically increased serum TSH levels, when goiter had already been established. However, during goitrogenesis IRS-1 expression was significantly increased during a period of time coinciding with the greater rate of thyroid weight gain. Thus, TSH positively modulated IRS-1 expression, probably depending on the activation or inhibition of other intracellular regulatory mechanisms. Therefore, when the mitogenic stimulus was predominant, IRS- 1 is up-regulated, whereas when the rate of mitosis decreases, impairing further thyroid gland weight gain, this pathway is down-regulated. The up-regulation of IRS-1 could stimulate and facilitate mitogenesis, since this protein plays an important role in intracellular mitogenic pathways $(21,22)$. After the establishment of hypothyroidism for a long period (21 days), IRS-1 is down-regulated in the thyroid, which could be due to the lack of a direct effect 
of thyroid hormones on the thyroid follicular cell. The possible effects of thyroid hormones on the regulation of thyroid cell proliferation has recently been demonstrated in an animal model of transgenic mice with a mutant thyroid hormone receptor $B$ that exerts a dominant negative effect. These mice have developed thyroid cancer; however, the thyroid carcinogenesis mechanism remains to be elucidated (23). In addition, we found that IRS-1 mRNA was negatively modulated in the liver of MMI-treated animals. In fact, in contrast to the thyroid gland, after 14 days of hypothyroidism, liver IRS-1 mRNA was already significantly decreased. Thus, our results show that increased IRS-1 was thyroid-specific during goitrogenesis and that the decreased liver IRS-1 expression detected in hypothyroid animals might explain, at least in part, the insulin resistance described in this model (24). Interestingly, the insulin resistance that develops during hypothyroidism seems to occur also in the thyroid gland and to overcome the positive control by TSH of IRS-1 mRNA expression. This biphasic modulation of IRS- 1 might be of physiological importance since the maintenance of thyroid weight despite high and maintained serum TSH levels should depend on the down-regulation of some intracellular mitogenic pathways.

Some studies have shown that overexpression of IR, IGF-IR and IR/IGF-IR hybrid receptors might occur in thyroid tumors, suggesting that this could be an important event in thyroid tumorigenesis (25-27). The present findings of decreased IRS-1 expression in the presence of sustained high serum TSH levels might indicate that increased IR activation alone should not lead to thyroid tumors, unless the intracellular receptor substrates are deregulated. Another possibility is that a chronic activation of IR may not promote IRS-1 down-regulation, differently from the insulin resistance that occurs in our model during hypothyroidism.
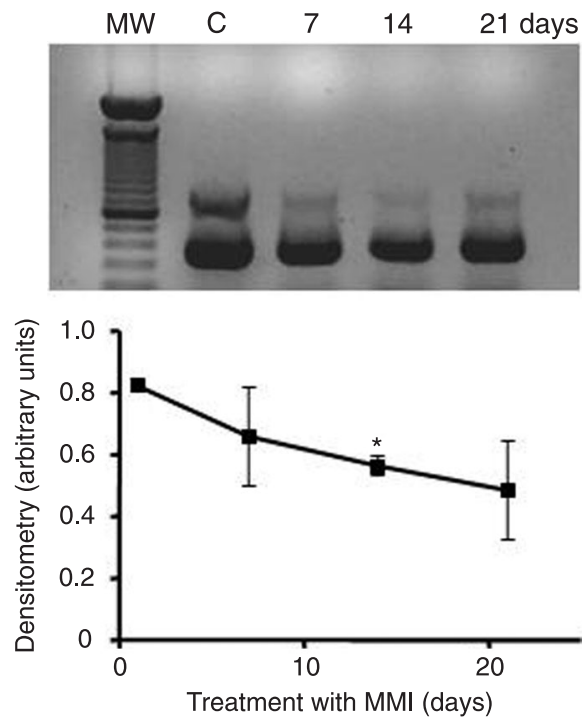

In the present study, we show for the first time that an important intracellular pathway involved in the mitogenesis of several cell types undergoes a biphasic modulation in the thyroid during physiological goitrogenesis during hypothyroidism. These findings are relevant for a better understanding of some apparently controversial findings regarding thyroid cell proliferation, since the majority of studies have been done in cell culture models under different assay conditions. Moreover, the effects of thyroid hormones on thyrocytes have not been fully understood. However, further studies are needed in order to better understand the factors that regulate IRS-1 expression in the thyroid gland in vivo. Also, the expression of IRS-2 should be investigated in this model, as well as the possible intracellular pathways that are activated during goitrogenesis and after goiter establishment.

\section{Acknowledgments}

We are grateful to Norma Lima de Araújo Faria, Advaldo Nunes Bezerra and Wagner Nunes Bezerra for technical assistance.
Figure 3. Liver insulin receptor substrate-1 (IRS-1) mRNA expression during hypothyroidism in rats. Liver IRS-1 mRNA expression was analyzed by semiquantitative RT-PCR. Hypothyroidism was induced by treatment with $0.03 \%$ methimazole (MMI) in drinking water for different periods of time $(7,14$, and 21 days). Data are reported as the mean \pm SEM for 2 rats per group in three experiments. ${ }^{*} \mathrm{P}<$ 0.01 compared to control (C) and to the other periods of $\mathrm{MMI}$ treatment (ANOVA followed by the Newman-Keuls multiple comparison test). $\mathrm{MW}=$ molecular weight; GAPDH = glyceraldehyde 3-phosphate dehydrogenase. 


\section{References}

1. Dumont JE, Lamy F, Roger P, Maenhaut C. Physiological and pathological regulation of thyroid cell proliferation and differentiation by thyrotropin and other factors. Physiol Rev 1992; 72: 667-697.

2. Medina DL, Santisteban P. Thyrotropin-dependent proliferation of in vitro rat thyroid cell systems. Eur J Endocrinol 2000; 143: 161-178.

3. Kimura T, Van Keymeulen A, Golstein J, Fusco A, Dumont JE, Roger PP. Regulation of thyroid cell proliferation by TSH and other factors: a critical evaluation of in vitro models. Endocr Rev 2001; 22: 631-656.

4. Burikhanov R, Coulonval K, Pirson I, Lamy F, Dumont JE, Roger PP. Thyrotropin via cyclic AMP induces insulin receptor expression and insulin co-stimulation of growth and amplifies insulin and insulin-like growth factor signaling pathways in dog thyroid epithelial cells. J Biol Chem 1996; 271: 29400-29406.

5. Deleu S, Pirson I, Coulonval K, Drouin A, Taton M, Clermont F, et al. IGF-1 or insulin, and the TSH cyclic AMP cascade separately control dog and human thyroid cell growth and DNA synthesis, and complement each other in inducing mitogenesis. Mol Cell Endocrinol 1999; 149: 41-51.

6. Kimura T, Dumont JE, Fusco A, Golstein J. Insulin and TSH promote growth in size of $\mathrm{PC} \mathrm{Cl3}$ rat thyroid cells, possibly via a pathway different from DNA synthesis: comparison with FRTL-5 cells. Eur J Endocrinol 1999; 140: 94-103.

7. Van Keymeulen A, Dumont JE, Roger PP. TSH induces insulin receptors that mediate insulin costimulation of growth in normal human thyroid cells. Biochem Biophys Res Commun 2000; 279: 202-207.

8. Gasperi M, Martino E, Manetti L, Arosio M, Porretti S, Faglia G, et al. Prevalence of thyroid diseases in patients with acromegaly: results of an Italian multi-center study. J Endocrinol Invest 2002; 25: 240245.

9. Clement S, Refetoff S, Robaye B, Dumont JE, Schurmans S. Low TSH requirement and goiter in transgenic mice overexpressing IGFI and IGF-Ir receptor in the thyroid gland. Endocrinology 2001; 142 : 5131-5139.

10. Van Obberghen E, Baron V, Delahaye L, Emanuelli B, Filippa N, Giorgetti-Peraldi S, et al. Surfing the insulin signaling web. Eur J Clin Invest 2001; 31: 966-977.

11. Myers MG Jr, Grammer TC, Wang LM, Sun XJ, Pierce JH, Blenis J, et al. Insulin receptor substrate-1 mediates phosphatidylinositol 3'kinase and p7056k signaling during insulin, insulin-like growth factor-1, and interleukin-4 stimulation. J Biol Chem 1994; 269: 2878328789.

12. LeRoith D, Werner H, Beitner-Johnson D, Roberts CT Jr. Molecular and cellular aspects of the insulin-like growth factor I receptor. Endocr Rev 1995; 16: 143-163.

13. Coulonval K, Vandeput F, Stein RC, Kozma SC, Lamy F, Dumont JE. Phosphatidylinositol 3-kinase, protein kinase B and ribosomal S6 kinases in the stimulation of thyroid epithelial cell proliferation by cAMP and growth factors in the presence of insulin. Biochem $J$
2000; 348 (Pt 2): 351-358.

14. Tanaka S, Wands JR. A carboxy-terminal truncated insulin receptor substrate-1 dominant negative protein reverses the human hepatocellular carcinoma malignant phenotype. J Clin Invest 1996; 98: 2100-2108.

15. Condorelli G, Formisano P, Miele C, Beguinot F. Thyrotropin regulates autophosphorylation and kinase activity in both the insulin and the insulin-like growth factor-I receptors in FRTL5 cells. Endocrinology 1992; 130: 1615-1625.

16. Takahashi S, Conti M, Prokop C, Van Wyk JJ, Earp HS III. Thyrotropin and insulin-like growth factor I regulation of tyrosine phosphorylation in FRTL-5 cells. Interaction between cAMP-dependent and growth factor-dependent signal transduction. J Biol Chem 1991; 266: 7834-7841.

17. Ariga M, Nedachi $T$, Akahori M, Sakamoto $H$, Ito $Y$, Hakuno F, et al. Signalling pathways of insulin-like growth factor-I that are augmented by cAMP in FRTL-5 cells. Biochem J 2000; 348 (Pt 2): 409416.

18. Ornellas DS, Nascimento DS, Christoph DH, Guggino WB, Morales $\mathrm{MM}$. Aldosterone and high- $\mathrm{NaCl}$ diet modulate $\mathrm{CIC}-2$ chloride channel gene expression in rat kidney. Pflugers Arch 2002; 444: 193-201.

19. Bradford MM. A rapid and sensitive method for the quantitation of microgram quantities of protein utilizing the principle of protein-dye binding. Anal Biochem 1976; 72: 248-254.

20. Laemmli UK. Cleavage of structural proteins during the assembly of the head of bacteriophage T4. Nature 1970; 227: 680-685.

21. Chang Q, Li Y, White MF, Fletcher JA, Xiao S. Constitutive activation of insulin receptor substrate 1 is a frequent event in human tumors: therapeutic implications. Cancer Res 2002; 62: 6035-6038.

22. Sesti G, Federici M, Hribal ML, Lauro D, Sbraccia P, Lauro R. Defects of the insulin receptor substrate (IRS) system in human metabolic disorders. FASEB J 2001; 15: 2099-2111.

23. Suzuki $\mathrm{H}$, Willingham MC, Cheng SY. Mice with a mutation in the thyroid hormone receptor beta gene spontaneously develop thyroid carcinoma: a mouse model of thyroid carcinogenesis. Thyroid 2002; 12: 963-969.

24. Cettour-Rose P, Theander-Carrillo C, Asensio C, Klein M, Visser TJ, Burger AG, et al. Hypothyroidism in rats decreases peripheral glucose utilisation, a defect partially corrected by central leptin infusion. Diabetologia 2005; 48: 624-633.

25. Belfiore A, Pandini G, Vella V, Squatrito S, Vigneri R. Insulin/IGF-I hybrid receptors play a major role in IGF-I signaling in thyroid cancer. Biochimie 1999; 81: 403-407.

26. Frittitta L, Sciacca L, Catalfamo R, Ippolito A, Gangemi P, Pezzino $V$, et al. Functional insulin receptors are overexpressed in thyroid tumors: is this an early event in thyroid tumorigenesis? Cancer 1999; 85: 492-498.

27. Vella V, Sciacca L, Pandini G, Mineo R, Squatrito S, Vigneri R, et al. The IGF system in thyroid cancer: new concepts. Mol Pathol 2001; 54: 121-124. 